\title{
Hubungan Gaya Kognitif dan Motivasi Berprestasi \\ Dengan Hasil Belajar
}

\author{
Benny Prasetiya \\ STAI Muhammadiyah Probolinggo \\ prasetiyabenny@gmail.com \\ Ulil Hidayah \\ STAI Muhammadiyah Probolinggo \\ Ulilhidayah31@gmail.com \\ Aries Dirgayunita \\ STAI Muhammadiyah Probolinggo \\ ega.psycho@gmail.com
}

\begin{abstract}
The purpose of this correlational study to determine the relationship of cognitive style and achievement motivation with learning outcomes PAI. The research data was sourced from the test results of cognitive style and tests of achievement motivation and learning outcomes PAI obtained from Value report cards. No results showed a significant relationship between cognitive style with PAI learning outcomes. There is a significant relationship between achievement motivation with learning outcomes PAI. Cognitive style and achievement motivation are jointly associated with learning outcomes PAI
\end{abstract}

Keywords: Cognitive, Motivation, Achievement, Learning Outcomes

Abstrak: Tujuan penelitian korelasional ini untuk mengetahui hubungan gaya kognitif dan motivasi berprestasi dengan hasil belajar PAI. Data penelitian bersumber dari tes hasil gaya kognitif dan tes motivasi berprestasi serta hasil belajar PAI yang diperoleh dari Nilai Raport. Hasil penelitian menunjukkan Tidak ada hubungan yang signifikan antara gaya kognitif dengan hasil belajar PAI. Terdapat hubungan yang signifikan antara motivasi berprestasi dengan hasil belajar PAI. Gaya kognitif dan motivasi berprestasi secara bersamasama berhubungan dengan hasil belajar PAI.

Kata Kunci: Kognitif, Motivasi, Berprestasi, Hasil Belajar 


\section{Pendahuluan}

Pembelajaran pendidikan agama Islam (PAI) adalah suatu upaya membelajarkan peserta didik agar dapat belajar, butuh belajar, terdorong belajar, mau belajar dan tertarik untuk terus menerus mempelajari agama Islam, baik untuk kepentingan mengetahui bagaimana cara beragama yang benar maupun mempelajari Islam sebagai pengetahuan. ${ }^{1}$ Tujuan pendidikan agama Islam adalah "membentuk kepribadian muslim yaitu suatu kepribadian yang seluruh aspeknya dijiwai oleh ajaran Islam. ${ }^{2}$

Hasil pembelajaran pendidikan agama Islam dapat berupa hasil nyata (actual out-comes) dan hasil yang diinginkan (desired out-comes), actual out-comes adalah hasil belajar yang dicapai peserta didik secara nyata karena digunakannya suatu metode pembelajaran pendidikan agama Islam tertentu yang dikembangkan sesuai dengan kondisi yang ada. Sedangkan desired out-comes merupakan tujuan yang ingin dicapai yang biasanya sering mempengaruhi keputusan perancang pembelajaran pendidikan agama Islam dalam melakukan pilihan suatu metode pembelajaran yang paling baik untuk digunakan sesuai dengan kondisi pembelajaran yang ada. Hasil pembelajaran menurut Muhaimin, dapat diklasifikasikan menjadi "keefektifan, efisiensi, dan daya tarik. Di samping perbedaan tiap individu, yang perlu diperhatikan dalam proses pembelajaran adalah variabel kondisi pembelajaran. Reigeluht and Merril mengelompokkan variabel kondisi pembelajaran menjadi tiga kelompok, yaitu: 1) tujuan dan karakteristik bidang studi, 2) kendala dan karakteristik bidang studi, dan 3) karakteristik pebelajar. Karakteristik si belajar adalah aspek-aspek atau kualitas perseorangan pebelajar, seperti bakat, minat, motivasi, orientasi tujuan, intelegensi, gaya kognitif, hasil belajar yang telah dimiliki dan lain-lain. ${ }^{3}$

Gronlund mengelompokkan hasil belajar atas; 1) pengetahuan; 2) pemahaman; 3) keterampilan berpikir; 4) keterampilan dalam penampilan; 5) keterampilan berkomunikasi; 6) keterampilan berhitung; 7) keterampilan belajar sambil bekerja; 8) keterampilan bersosialisasi; 9) sikap; 10) minat; 11) apresiasi;

\footnotetext{
1 Muhaimin, Paradigma Pendidikan Islam (Upaya Mengefektifkan Pendidikan Agama Islam di Sekolah), (Bandung Remaja Rosdakarya, 2002). 183.

2 Zuhairini, dkk, Metodologi Pendidikan Agama, (Jakarta: Ramadhani,1995), 159.

${ }^{3}$ Rufi'i . Dampak Gaya Kognitif Terbadap Perolehan Belajar Konsep Statistika.W AHANA

$\backslash V$ olume 57, ISSN : 0853 - 4403
} 
dan 12) penyesuaian diri. ${ }^{4}$ Sedangkan Bloom mengelompokkan hasil belajar atas tiga ranah, yaitu: 1) ranah kognitif; berhubungan dengan perubahan pengetahuan; 2) ranah afektif; berhubungan dengan perkembangan atau perubahan sikap sebagai hasil dari proses belajar, dan 3) ranah psikomotorik; berhubungan dengan penguasaan keterampilan motorik. ${ }^{5}$

Gaya kognitif adalah cara konsisten seseorang merespon dan menggunakan stimuli dalam lingkungan belajar ( Anon,1). konsep gaya kognitif timbul sebagai usaha-usaha dalam bidang psikologi perbedaan individu yang berkaitan dengan perbedaan tingkah laku kognitif manusia. Para peneliti menyelidiki konsep gaya kognitif untuk mengetahui bagaimana sesungguhnya pikiran itu berfungsi memproses informasi yang masuk, dan bagaimana pikiran dipengaruhi oleh persepsi seseorang. Penyelidikan tentang gaya kognitif adalah hasil usaha witkin, Halzmann, Gardner, kogan, messick dan rekan mereka. Kedudukan gaya kognitif dalam proses pembelajaran tidak dapat di abaikan.

Hal ini sesuai dengan pandangan Reigeluth bahwa dalam variabel pembelajaran, gaya kognitif merupakan salah satu karakteristik peserta didik yang masuk dalam variabel kondisi pembelajaran, di samping karakteristik peserta didik lainnya seperti motivasi, sikap, bakat dan minat. ${ }^{6}$ Messick, Lourdusary mengemukakan: 1) seperti dikemukakan oleh Lordusary menerangkan gaya kognitif sebagai sikap, kecenderungan atau strategi tabiat yang stabil yang mementukan gaya kebiasaan seseorang dalam menanggap, mengingat, berpikir, dan menyelesaikan masalah. Selanjutnya ia mengemukakan beberapa jenis gaya kognitif yaitu : (1) Field Independent versus Field dependent yang mencerminkan suatu cara analisis seseorang dalam menghadapi alam sekitar, (2) gaya pembentukan konsep yang mencerminkan ciri-ciri individu dalam menggunkan suatu jenis rangsangan tertentu dan hubungannya sebagai asa untuk membentuk konsep, (3) keluasan katagori yang berhubungan dengan kecenderungan seseorang dalam menyusun katagori konsep secara luas atau sempit, (4) leveling versung sharpening sehubungan dengan perbedaan seseorang dalam pemerosesan ingatan, antara menyukai mengingat sesuatu dengan

${ }^{4}$ G. Rowland and C. M. Regeluth (ed)Tjeerd plomp and donald P Ely, Task Analysis International Encyclopedia Educational Technology. Second Edition (Cambridge: Printed and Bound in Great Britain Cambridge University Press, 1978: 3).

${ }^{5}$ Benyamin S. Bloom, Taxonomy of Educational Objective (London: Longman, 1970:7-9).

${ }^{6}$ Herbert G. Hicks and Gullet G. Ray, Organization Theory and Behavior, terjemahan G. Kartasapoetra,(Jakarta: PT. Bumi Aksara, 1996:121-126). 
menyamakan terhadap hal-hal yang telah diingatnya atau membuat ciri baru dan menginatnya dalam ciri tersebut, (5) Scanning yang mencerminkan kecenderungan seseorang dalam memfokuskan perhatian pada suatu informasi.

Dari beberapa definisi dan pengertian yang telah diuraikan dapat disimpulkan bahwa gaya kognitif adalah gaya dari tiap individu-individu yang sifatnya relatif stabil dan menjadi kebiasaan individu-individu tersebut dalam hal menerima mengingat, berpikir, dan menyelesaikan suatu masalah.

Motivasi dapat diartikan sebagai suatu proses psikologi yang mencerminkan interaksi antara sikap, kebutuhan, persepsi, dan keputusan yang terjadi pada diri sesorang. Proses psikologi timbul diakibatkan oleh faktor di dalam diri seseorang itu sendiri yang disebut intrinsic dan extrinsic. Faktor di dalam diri seseorang bisa berupa kepribadian, sikap, pengalaman dan pendidikan, atau berbagai harapan, cita-cita yang menjangkau ke masa depan sedang faktor dari luar diri dapat ditimbulkan oleh berbagi faktor-faktor lain yang sangat kompleks. Tetapi baik faktor ekstrinsik maupun faktor instrinsik motivasi timbul karena adanya rangsangan. ${ }^{7}$

Motivasi dapat didefinisikan sebagai kekuatan, dorongan, kebutuhan yang rumit atau mekanisme memulai dan memelihara kegiatan untuk mencapai prestasi seseorang. ${ }^{8}$ Sejalan dengan pengertian tersebut, motivasi dapat diartikan sebagai suatu dorongan dari dalam diri individu untuk memenuhi kebutuhan dalam mencapai tujuan yang diinginkan.

Hicks and Gullet, membedakan motivasi dalam dua kelompok yaitu motivasi internal dan motivasi eksternal. Motivasi internal adalah kebutuhan, keinginan dan harapan yang terdapat dalam pribadi seseorang yang menentukan berbagai pandangan, yang menurut giliran akan memimpin tingkah laku dalam situasi yang khusus. Sedangkan motivasi eksternal meliputi kekuatan yang ada di luar diri individu seperti halnya faktor pengendalian oleh manajer, juga meliputi hal-hal yang berkaitan dengan pekerjaan seperti gaji/upah, kondisi kerja, kebijaksanaan organisasi dan pekerjaan yang mengandung hal-hal penghargaan, pengembangan dan tanggungjawab.

7 (Wahjosumidjo, 1984: 50)

8 Feldman, Robert., Understanding Psychology (New York: Mc-Graw-Hill), 1987: 176)

${ }^{9}$ Azwar, Syafuddin., Pengantar Psikologi Inteligensi (Yogyakarta: Pustaka Pelajar), 1996:450) 
Teori Harapan. Vroom mengembangkan sebuah teori motivasi berdasarkan jenis pilihan yang dibuat orang untuk mencapai tujuan, alih-alih berdasarkan kebutuhan internal. Teori harapan (expectancy theory) memiliki tiga asumsi pokok:1) setiap individu percaya bahwa bial ia berperilaku dengan cara tertentu ia akan memperoleh hal tententu. Ini disebut harapan hasil (outcome expectancy). 2) setiap hasil mempunyai nilai, atau daya tarik bagi orang tertentu. Ini disebut valensi (valence), 3) setiap hasil berkaitan dengan suatu persepsi mengenai seberapa sulit mencapai hasil tersebut. Ini disebut harapan usaha (effort expectancy). Motivasi orang dapat dijelaskan dari ketiga kombinasi ini bahwa: 1) suatu perilaku tertentu akan menghasilkan hasil tertentu, 2) hasil tertentu punya nilai positif baginya, 3) hasil tersebut dapat dicapai dengan usaha yang dilakukan seseorang. Jadi motivasi dalam teori harapan adalah keputusan untuk mencurahkan usaha. ${ }^{10}$ Dari pemikiran yang telah dipaparkan di atas, aspek-aspek Gaya kognitif dan motivasi berprestasi di jadikan variabel independent dan hasil belajar merupakan variabel dependent.

\section{Metode Penelitian}

Penelitian ini dilakukan pada peserta didik SMKN 1 Kraksaan. Sesuai dengan permasalahan yang diteliti dan tujuan penelitian yang ingin dicapai, penelitian bersifat verifikasi hipotesis menggunakan metode survei dengan pendekatan teknik korelasional. Hubungan antara variabel terikat dan variabel-variabel bebas penelitian ini dapat digambarkan dalam bentuk konstelasi .

Populasi dalam penelitian ini adalah Peserta didik SMKN 1 Kraksaan Probolinggo. Teknik pengambilan sample menggunakan purporsif sampling. Yaitu menunjuk kelas XI APK 1 sebanyak 34 Peserta didik dengan alasan kelas ini merupakan kelas unggulan. Instrument dalam penelitian ini menggunakan tes gaya kognitif dan motivasi berprestasi. Sebelum tes dilakukan terlebih dahulu diuji validitas dan reabilitas. Dalam penelitian ini analisis data dilakukan dengan menggunakan statistik yaitu: Regresi sederhana dan jamak, korelasi sederhana, parsial, dan jamak semua pengukuran dilakukan pada taraf signifikansi $\alpha 0,05$.

${ }^{10}$ (F. Faules, 2000: 124-125) 
Sebelum dilakukan pengujian hipotesis penelitian, terlebih dahulu dilakukan uji persyaratan analisis meliputi uji normalitas dan uji homogenitas.

\section{Pengujian Persyaratan Analisis}

\section{Uji Normalitas}

Uji normalitas bertujuan untuk mengetahui normal atau tidaknya suatu distribusi data. Uji normalitas ini membandingkan antara hasil perolehan data gaya kognitif (X1), Motivasi berprestasi (X2) dan Hasil belajar PAI (Y) dengan data berdistribusi normal yang memiliki mean dan strandar deviasi yang sama dengan hasil perolehan data. Untuk melakukan uji normalitas dengan menggunakan uji kolmogorof-Smirnov. Ketentuan dalam uji galat adalah bila asymp.Sig atau $\boldsymbol{P}$. value $>0,05$, menujukkan data berdistribusi normal. Akan tetapi jika asymp.Sig atau $\boldsymbol{P}$. value $<0,05$ menunjukkan data tidak berdistribusi normal. Dalam uji normalitas ini, Dari hasil pengujian normalitas variabel-varibael penelitian, selanjutnya secara keseluruhan hasil perhitungan tersebut dapat dilihat pada rangkuman tabel 1.

\section{Tabel 1}

Uji Normalitas

One-Sample Kolmogorov-Smirnov Test

\begin{tabular}{|ll|c|c|c|}
\hline & $\begin{array}{c}\text { Hasil Belajar } \\
\text { PAI }\end{array}$ & $\begin{array}{c}\text { Gaya } \\
\text { Kognitif }\end{array}$ & $\begin{array}{c}\text { Motivasi } \\
\text { Berprestas } \\
\text { i }\end{array}$ \\
\hline $\mathrm{N}$ & Mean & 81.65 & 52.53 & 78.09 \\
Normal & Std. & 2.398 & 4.223 & 9.959 \\
Parameters & Deviation & & & \\
& Absolute & .136 & .103 & .184 \\
Most Extreme & Positive & .136 & .088 & .072 \\
Differences & Negative & -.099 & -.103 & -.184 \\
& .792 & .602 & 1.070 \\
Kolmogorov-Smirnov Z & .558 & .862 & .202 \\
Asymp. Sig. (2-tailed) & &
\end{tabular}

a. Test distribution is Normal.

b. Calculated from data.

Berdasarkan Uji normalitas di atas maka angka signifikansi uji asymp.Sig atau $\boldsymbol{P}$. value $>0,05$ atau $0,558>0,05$ (hasil belajar PAI), 0,862 
$>0,05$ (hasil gaya kognitif) dan 0,202 >0,05 (motvasi beprestasi) maka data menujukkan berdistribusi normal.

\section{Uji Linieritas}

Tujuan Uji linieritas adalah untuk mengetahui hubungan antara variebel bebas dan terikat linier atau tidak. Pengujian dilakukan dengan bantuan SPSS 21 for Windows. Criteria pengujian linieritas adalah jika nilai signifikansi Deviation From Linierity lebih besar 0,05 maka hubungan antara variabel bebas dan terikat adalah linier. Uji linieritas pertama adalah variabel Gaya kognitif $\left(\mathrm{X}_{1}\right)$ terhadap hasil belajar $(\mathrm{Y})$. Berdasarkan hasil pengujian dapat diinterpretasikan sig. dari Deviation from linierity adalah 0,677. Artinya ini lebih besar dari pada $\mathbf{0 , 0 5}(\mathbf{0 , 6 7 7}>\mathbf{0 , 0 5})$. Dengan demikian dapat disimpulkan bahwa hubungan antara Variabel Y dan Variabel X1 adalah linier. Uji linieritas yang kedua adalah motivasi berprestasi $\left(\mathrm{X}_{2}\right)$ terhadap hasil belajar (Y). Hasil perhitungan keberartian dan linieritas tertera Berdasarkan hasil pengujian dapat diinterpretasikan sig. dari Deviation from linierity adalah 0,730. Artinya ini lebih besar dari pada 0,05 (0,730>0,05). Dengan demikian dapat disimpulkan bahwa hubungan antara Variabel Y dan Variabel X2 adalah linier. Uji linieritas yang ketiga adalah regresi ganda secara bersama-sama antara variabel Gaya kognitif $\left(\mathrm{X}_{1}\right)$ dan motivasi berprestasi $\left(\mathrm{X}_{2}\right)$ terhadap hasil belajar $(\mathrm{Y})$. Selanjutnya dilakukan uji linieritas dan keberartian persamaan regresi menggunakan Uji multikorelasi (gejala multikollinieritas). Hasil perhitunganUji multikorelasi tertera pada tabel 2

Hasil perhitungan keberartian dan linieritas tertera pada tabel 2.

Tabel 2 Uji multikorelasi

Coefficients $^{\mathrm{a}}$

\begin{tabular}{|ll|c|c|}
\hline \multicolumn{2}{|l|}{ Model } & \multicolumn{2}{|c|}{ Collinearity Statistics } \\
\cline { 3 - 4 } & Tolerance & VIF \\
\hline \multirow{2}{*}{1} & Motivasi Berprestasi & .979 & 1.021 \\
& Gaya Kognitif & .979 & 1.021 \\
\hline
\end{tabular}

a. Dependent Variable: Hasil Belajar PAI

Berdasarkan hasil pengujian pada tabel 2 dapat diinterpretasikan Nilai $\mathrm{VIF}=\mathbf{1 , 0 2 1}$. Artinya nilai VI F ini lebih kecil daripada $10 \quad \mathbf{( 1 , 0 2 1 < 1 0 )}$. Dengan demikian tidak terjadi multikolinieritas diantara variabel bebas. Dengan 
demikian dapat disimpulkan bahwa hubungan antara Variabel Y dan Variabel $\mathrm{X} 1, \mathrm{X} 2$ adalah linier. Selanjutnya dari persamaan regresi ganda tersebut dapat diinterpretasikan bahwa apabila dilihat secara bersama-sama hubungan Gaya Kognitif dan motivasi berprestasi dengan hasil belajar diukur dengan instrumen yang digunakan dalam penelitian ini, maka setiap kenaikan skor akan diikuti dengan kenaikan skor hasil belajar.

\section{Pengujian Hipotesis}

Penelitian ini mengajukan tiga hipotesis yang perlu diuji secara empiris. Semua hipotesis adalah dugaan tentang hubungan antara Gaya Kognitif, motivasi berprestasi, baik secara sendiri-sendiri maupun secara bersama-sama dengan hasil belajar PAI.

\section{Hubungan antara Gaya kognitif dengan Hasil Belajar}

Hipotesis pertama penelitian ini adalah terdapat hubungan positif antara Gaya Kognitif dengan hasil belajar. Pengujian hipotesis pertama dilakukan dengan menggunakan rumus korelasi Pearson Product Moment. Berdasarkan hasil perhitungan diperoleh koefisien korelasi antara Gaya kognitif $\left(\mathrm{X}_{1}\right)$ dengan hasil belajar $(Y), r_{y 1}=0,27$. Angka ini mengisyaratkan bahwa hubungan antara Gaya kognitif dengan hasil belajar adalah negatif. Hasil perhitungan pengujian keberartian koefisien korelasi dengan menggunakan SPSS 21. Dari hasil analisis diperoleh bahwa besarnya koefiensi korelasi sebesar 0,270 dengan $P$ $V$ alue 0,122. Dengan jumlah responden sebanyak 34, maka $\mathrm{r}$ tabel pada $\alpha$ $=0,05$ sebesar 0,27. Hal ini menunjukkan bahwa $r$ hitung sama dengan $r$ tabel $(0,27=0,27)$. Dengan demikian dapat disimpulkan bahwa koefisien koerelasi sebesar 0,27 adalah tidak signifikan. Sedangkan apabila menggunakan P-value, maka diperoleh koefisien sebesar 0,122. Karena P-Value lebih besar dari 0,05 bahkan 0,01 maka hal ini dinyatakan bahwa koefisien korelasi sebesar 0,27 tidak signifikan. Hasil ini memberikan makna bahwa tidak ada hubungan antara gaya kognitif dan hasil belajar PAI. Nilai R square sebesar 0,073 menunjukkan bahwa variabel gaya kognitif berkontibusi terhadap Hasil belajar PAI sebesar 1,73\%, sedangkan sisanya sebesar 92,7\% dijelaskan oleh faktor lain yang tidak dianalisis dalam penelitian ini. 


\section{Hubungan antara Motivasi berprestasi dengan Hasil Belajar}

Hipotesis pertama penelitian ini adalah terdapat hubungan positif antara motivasi berprestasi dengan hasil belajar. Pengujian hipotesis kedua dilakukan dengan menggunakan rumus korelasi Pearson Product Moment. Berdasarkan hasil perhitungan diperoleh koefisien korelasi antara motivasi berprestasi $\left(\mathrm{X}_{2}\right)$ dengan hasil belajar (Y), $\mathrm{r}_{\mathrm{y} 2}=0$,392. Angka ini mengisyaratkan bahwa hubungan antara motivasi berprestasi dengan hasil belajar adalah positif. Hasil perhitungan pengujian keberartian koefisien korelasi dengan menggunakan SPSS 21

Dari hasil analisis diperoleh bahwa besarnya koefiensi korelasi sebesar 0,392 dengan P-Value 0,022. Dengan jumlah responden sebanyak 34, maka $\mathrm{r}$ tabel pada $\alpha=0,05$ sebesar 0,27. Hal ini menunjukkan bahwa $r$ hitung sama dengan $r$ tabel $(0,392>0,27)$. Dengan demikian dapat disimpulkan bahwa koefisien koerelasi sebesar 0,2392 adalah signifikan. Sedangkan apabila menggunakan P-value, maka diperoleh koefisien sebesar 0,022. Karena PValue lebih kecil dari 0,05 maka hal ini dinyatakan bahwa koefisien korelasi sebesar 0,392 signifikan. Hasil ini memberikan makna bahwa ada hubungan antara gaya kognitif dan hasil belajar PAI. Nilai R square sebesar 0,154 menunjukkan bahwa variabel motivasi berprestasi berkontibusi terhadap Hasil belajar PAI sebesar 15,4\%, sedangkan sisanya sebesar 84,6 \% dijelaskan oleh faktor lain yang tidak dianalisis dalam penelitian ini.

\section{Hubungan antara Gaya Kognitif dan motivasi berprestasi secara bersama-sama dengan Hasil Belajar}

Hipotesis ketiga penelitian ini adalah terdapat hubungan positif secara bersama-sama antara Gaya Kognitif dan motivasi berprestasi dengan hasil belajar. Pengujian hipotesis ketiga dilakukan dengan hasil analisis multivariate dengan regresi ganda Gaya kognitif dan motivasi berprestasi dengan hasil belajar PAI. Hasil statistik diketahui nilai korelasi $r$ hitung sebesar $r_{\mathrm{y} 3}=0,448$. Angka ini mengisyaratkan bahwa hubungan secara bersama-sama antara Gaya Kognitif dan motivasi berprestasi dengan hasil belajar adalah positif. Hasil perhitungan pengujian keberartian koefisien korelasi dengan menggunakan SPSS 21

Uji signifikansi koefisien korelasi diperoleh dari tabel Model Summary. Terlihat pada baris pertama koefisien korelasi $=0,448$ dan $\mathrm{F}_{\text {hitung }}\left(\mathrm{F}_{\text {change }}\right)=$ 
3,886 dengan p-value $=0,031>0,05$. Hal ini berarti $\mathrm{H}_{0}$ ditolak. $\boldsymbol{R}$ Square merupakan koefisien Determinasi. Besarnya $R$ Square adalah $\left(\mathbf{R}^{2}\right)$ adalah 0,2 $=20 \%$. Artinya besarnya pengaruh Gaya Kognitif dan motivasi berprestasi terhadap hasil belajar PAI $20 \%$ dan besarnya variabel lain yang mempengaruhi variable hasil belajar PAI adalah $\quad 80 \%$. Nilai R square sebesar 0,2 menunjukkan bahwa variabel Gaya kognitif dan motivasi berprestasi berkontibusi terhadap Hasil belajar PAI sebesar 20\%, sedangkan sisanya sebesar $80 \%$ dijelaskan oleh faktor lain yang tidak dianalisis dalam penelitian ini.

\section{Pembahasan}

Penelitian ini mendiskripsikan dan menguji hubungan dari variabel terikat yaitu Gaya Kognitif dan motivasi berprestasi terhadap hasil belajar PAI. Teknik analisis yang digunakan adalah korelasi dan regresi ganda. Uji prasyarat yang harus dilakukan yaitu uji normalitas dengan menggunakan Uji kolmogorofsmirnov dan uji linieritas. Ketentuan dalam uji galat adalah bila asymp.Sig atau P. value $>0,05$, menujukkan data berdistribusi normal. Akan tetapi jika asymp.Sig atau P. value $<0,05$ menunjukkan data tidak berdistribusi normal. Hasil perhitungan menunjukkan bahwa variabel independen Gaya kognitif mempunyai angka signifikansi uji asymp.Sig 0,862. Nilai tersebut $>0,05$. Variabel motivasi berprestasi mempunyai angka signifikansi uji asymp.Sig 0,202 . Nilai tersebut $>0,05$. Sedangkan Untuk variabel dependen hasil belajar PAI mempunyai angka signifikansi uji asymp.Sig 0,558. Nilai tersebut $>0,05$. Dengan demikian bahwa variabel-variebl tersebut menujukkan berdistribusi normal.

Selanjutnya Uji prayarat analisis yang kedua dalam penelitian ini adalah uji linieritas.. Pengujian dilakukan dengan bantuan SPSS 21 for Windows. Kriteria pengujian linieritas adalah jika nilai signifikansi Deviation From Linierity lebih besar 0,05 maka hubungan antara variabel bebas dan terikat adalah linier. Uji linieritas pertama adalah variabel Gaya kognitif $\left(\mathrm{X}_{1}\right)$ terhadap hasil belajar $(\mathrm{Y})$. Hasil perhitungan keberartian dan linieritas Deviation from linierity adalah $\mathbf{0 , 6 7 7}$. Artinya ini lebih besar dari pada 0,05 (0,677>0,05). Dengan demikian dapat disimpulkan bahwa hubungan antara Variabel Y dan Variabel X1 adalah linier. Uji linieritas yang kedua adalah motivasi berprestasi $\left(\mathrm{X}_{2}\right)$ terhadap hasil belajar (Y). Hasil perhitungan keberartian dan linieritas berdasarkan hasil pengujian pada diinterpretasikan sig. dari Deviation from linierity adalah $\mathbf{0 , 7 3 0}$. 
Artinya ini lebih besar dari pada 0,05 (0,730>0,05). Dengan demikian dapat disimpulkan bahwa hubungan antara Variabel Y dan Variabel X2 adalah linier. Uji linieritas yang ketiga adalah regresi ganda secara bersama-sama antara variabel Gaya kognitif $\left(\mathrm{X}_{1}\right)$ dan motivasi berprestasi $\left(\mathrm{X}_{2}\right)$ terhadap hasil belajar (Y). Selanjutnya dilakukan uji linieritas dan keberartian persamaan regresi menggunakan Uji multikorelasi (gejala multikollinieritas). Hasil perhitungan Uji multikorelasi berdasarkan hasil pengujian pada tabel 4.5 dapat diinterpretasikan Nilai VIF=1,021. Artinya nilai VI F ini lebih kecil daripada $10 \quad(\mathbf{1 , 0 2 1 < 1 0 )}$. Dengan demikian tidak terjadi multikolinieritas diantara variabel bebas. Dengan demikian dapat disimpulkan bahwa hubungan antara Variabel Y dan Variabel $\mathrm{X} 1, \mathrm{X} 2$ adalah linier. Selanjutnya dari persamaan regresi ganda tersebut dapat diinterpretasikan bahwa apabila dilihat secara bersama-sama hubungan Gaya Kognitif dan motivasi berprestasi dengan hasil belajar diukur dengan instrumen yang digunakan dalam penelitian ini, maka setiap kenaikan skor akan diikuti dengan kenaikan skor hasil belajar.

Penelitian ini bertujuan untuk mengetahui dan menganalisis hubungan Gaya kognitif dan motivasi berprestasi dengan hasil belajar PAI Siswa kelas XI APK1 SMKN Kraksaan. Hasil belajar adalah kemampuan yang diperoleh peserta didik melalui proses belajar mengajar di sekolah dalam kurun waktu tertentu yang meliputi domain kognitif, afektif, dan psikomotorik yang dinyatakan dengan angka dan diukur dengan menggunakan tes hasil belajar. Hasil belajar yang dimiliki siswa menurut Gagne dipengaruhi oleh 3 tiga domain, yaitu: (1) domain kognitif; meliputi: pengetahuan, pemahaman, dan keterampilan berpikir, (2) domain afektif; meliputi: sikap, minat, apresiasi, dan penyesuaian diri, dan (3) domain psikomotorik; meliputi keterampilan dalam penampilan, keterampilan berkomunikasi, keterampilan berhitung, keterampilan belajar sambil bekerja, dan keterampilan dalam hubungan social. Pada penelitian ini akan menggali variabel Gaya kognitif dan motivasi berprestasi yang berhubungan dengan Hasil belajar.

Hipotesis pertama adalah dari hasil analisis dengan menggunakan korelasi Product Moment. Berdasarkan hasil perhitungan diperoleh koefisien korelasi antara Gaya kognitif $\left(\mathrm{X}_{1}\right)$ dengan hasil belajar $(\mathrm{Y}), \mathrm{r}_{\mathrm{y} 1}=0,27$ dengan P-Value 0,122. Dengan jumlah responden sebanyak 34, maka $\mathrm{r}$ tabel pada $\alpha=0,05$ sebesar 0,27. Hal ini menunjukkan bahwa $r$ hitung sama dengan $r$ tabel $(0,27=0,27)$. Dengan demikian dapat disimpulkan bahwa koefisien koerelasi sebesar 0,27 adalah tidak signifikan. Sedangkan apabila menggunakan P-value, 
maka diperoleh koefisien sebesar 0,122. Karena P-Value lebih besar dari 0,05 bahkan 0,01 maka hal ini dinyatakan bahwa koefisien korelasi sebesar 0,27 tidak signifikan. Hasil ini memberikan makna bahwa tidak ada hubungan antara gaya kognitif dan hasil belajar PAI. Nilai R square sebesar 0,073 menunjukkan bahwa variabel gaya kognitif berkontibusi terhadap Hasil belajar PAI sebesar $1,73 \%$, sedangkan sisanya sebesar $92,7 \%$ dijelaskan oleh faktor lain yang tidak dianalisis dalam penelitian ini.

Hipotesis kedua menunjukkan bahwa terdapat hubungan yang positif dan signifikan antara motivasi berprestasi terhadap hasil belajar. Dari hasil analisis dengan menggunakan korelasi Product Moment diperoleh harga koefisien koefiensi korelasi sebesar 0,392 dengan P-Value 0,022. Dengan jumlah responden sebanyak 34, maka $r$ tabel pada $\alpha=0,05$ sebesar 0,27. Hal ini menunjukkan bahwa $r$ hitung sama dengan $r$ tabel $(0,392>0,27)$. Dengan demikian dapat disimpulkan bahwa koefisien koerelasi sebesar 0,2392 adalah signifikan. Sedangkan apabila menggunakan P-value, maka diperoleh koefisien sebesar 0,022. Karena P-Value lebih kecil dari 0,05 maka hal ini dinyatakan bahwa koefisien korelasi sebesar 0,392 signifikan. Hasil ini memberikan makna bahwa ada hubungan antara gaya kognitif dan hasil belajar PAI.

Nilai R square sebesar 0,154 menunjukkan bahwa variabel motivasi berprestasi berkontibusi terhadap Hasil belajar PAI sebesar 15,4\%, sedangkan sisanya sebesar $84,6 \%$ dijelaskan oleh faktor lain yang tidak dianalisis dalam penelitian ini.

Hipotesis ketiga menunjukkan bahwa terdapat hubungan yang positif dan signifikan antara gaya kognitif dengan motivasi berprestasi secara bersama-sama terhadap hasil belajar PAI. Uji signifikansi koefisien korelasi diperoleh dari tabel Model Summary. Terlihat pada baris pertama koefisien korelasi $(=0,448$ dan $\mathrm{F}_{\text {hitung }}\left(\mathrm{F}_{\text {change }}\right)=3,886$ dengan p-value $=0,031>0,05$. Hal ini berarti $\mathrm{H}_{0}$ ditolak. $\boldsymbol{R}$ Square merupakan koefisien Determinasi. Besarnya R Square adalah $\left(\mathrm{R}^{2}\right)$ adalah 0,2 =20\%. Artinya besarnya pengaruh Gaya Kognitif dan motivasi berprestasi terhadap hasil belajar PAI $20 \%$ dan besarnya variabel lain yang mempengaruhi variable hasil belajar PAI adalah $\quad 80 \%$. Nilai R square sebesar 0,2 menunjukkan bahwa variabel Gaya kognitif dan motivasi berprestasi berkontibusi terhadap Hasil belajar PAI sebesar 20\%, sedangkan sisanya sebesar $80 \%$ dijelaskan oleh faktor lain yang tidak dianalisis dalam penelitian ini. 


\section{Punutup}

Berdasarkan hasil penelitian dan pembahasan pada Bab sebelumnya maka dapat diambil kesimpulan bahwa : 1) Tidak ada hubungan yang signifikan antara gaya kognitif dengan hasil belajar PAI. Hasil perhitungan diperoleh koefisien korelasi $\mathrm{r}_{\mathrm{y} 1}=0,27$ dengan $P$-V alue 0,122. $\mathrm{r}$ hitung $=\mathrm{r}$ tabel dan $P$-Value lebih besar dari 0,05 bahkan 0,01 maka hal ini dinyatakan bahwa koefisien korelasi sebesar 0,27 tidak signifikan. 2) Terdapat hubungan yang signifikan antara motivasi berprestasi dengan hasil belajar PAI. Hasil perhitungan diperoleh koefisien korelasi $\mathrm{r}_{\mathrm{y} 2}=0,392$ dengan $P$-V alue 0,022. $\mathrm{r}$ hitung $>\mathrm{r}$ tabel dan $P$ $V$ alue lebih kecil dari 0,05. Maka hal ini dinyatakan bahwa koefisien korelasi sebesar 0,392 signifikan. 3) Gaya kognitif dan motivasi berprestasi berhubungan dengan hasil belajar PAI. Hal ini dibuktikan hasil analisis multivariate dengan regresi ganda dengan koefisien korelasi $\left(=0,448\right.$ dan $\mathrm{F}_{\text {hitung }}\left(\mathrm{F}_{\text {change }}\right)=3,886$ dengan $\mathrm{p}$-value $=0,031>0,05$.

Secara bersama-sama minat gaya kognitif dan motivasi berprestasi berhubungan dengan hasil belajar PAI. Hasil analisis multivariate dengan regresi ganda yang memiliki peran dominan dan berhubungan signifikan dengan hasil belajar PAI yaitu gaya kognitif dan motivasi berprestasi. Para guru dan pihakpihak yang berwenang diharapkan dapat memperhatikan faktor-faktor tersebut baik gaya kognitif maupun motivasi berprestasi, sehingga dapat mendukung tercapainya hasil belajar PAI dengan baik. Hasil penelitian ini dapat diimplikasikan bagi para peserta didik khususnya untuk dapat meningkatkan gaya kognitif maupun motivasi berprestasi dari dalam sehingga dapat mengatasi kendala dalam penguasaaan ilmu pengetahuan khususnya berkaitan hasil belajar PAI. 


\section{Bibliograpy}

Abraham H. Maslow, Motivasi dan Kepribadian I, (PT. Pustaka Binaman pressindo, 1994),

Aununrrahman, Belajar dan Pembelajaran, (Bandung: Alfabeta), 2012.

Azwar, Syafuddin., Pengantar Psikologi Inteligensi (Yogyakarta: Pustaka Pelajar), 1996.

Benyamin S. Bloom, Taxonomy of Educational Objective (London: Longman, 1970),

David M. Merrill and David G Twitcell, Instructional Design Theory (New Jersey: Educational Technology Publication Englewood Cliffs, 1994),

Fred Luthans, Organizational Behavior, (New York: McGraw-Hill Inc, 1995

G. Rowland and C. M. Regeluth (ed)Tjeerd plomp and donald P Ely, Task Analysis International Encyclopedia Educational Technology. Second Edition (Cambridge: Printed and Bound in Great Britain Cambridge University Press, 1996)

Garrison, K.C. \& Magoon, R.A., Educational Psychology: An Integration of Psychology and Educational Practices (Colombus: Charles E. Merril Publsing Company), 1972.

Ghokhale, Anuradha A Collaborative learning Enchaces Critical Thinking, 2004. (http//scholar.lib.vt.edu/journals/JTE/jte-v7n-1/gokhle.jte-v7n1)

Goldstein, Norman L., and E Brophy, Education Psycholog. New York: Longman. 1990.

Goleman, Daniel., Emotional Intelligent Why It Can Matter More Than IQ, (New York: Bantam Books) 1995.

Good Thomas L dan Jere E. Brophy, Educational Psychology,( New York: Longman, 1990),

Hamzah B. Uno, Teori Motivasi dan Pengukurannya, Analisis di Bidang Pendidikan, Jakarta: Bumi Aksara, 2008,

Handoko, M.T., 1998. Klarifikasi Nilai Sebagai Pendekatan Alternatif Bagi Terapi Peningkatan Motivasi Belajar. (Semarang: Universitas Katolik Soegiopranato)

Hasibuan, Manajemen Sumber Daya Manusia, (Jakarta: Haji Masagung, 1999), p.65 
Herbert G. Hicks and Gullet G. Ray, Organization Theory and Behavior, terjemahan G. Kartasapoetra,(Jakarta: PT. Bumi Aksara, 1996),

Hoy Wayne K and Miskel Cecil G, Educational Administration;Theory, Research, and Practice, (New York: Random House, 1987),

Hsion, Yu-ping, The effect of Cognitive Styles and Learning Strategies in Hypermedia

Iswanti. Pengarub Motivasi Berprestasi Dan Peran Orangtua dengan Prestasi Belajar Siswa SMU Tarakanita I. TARAKANITA Vol 2 No 2 / 176 ISSN 1693-6744

Larse, Earnie dan Hegarty, Carol., Percaya Diri alih bahasa Meitasari Tjandrasa (Jakarta: Profesional Book), 1997.

LaurieJ. Mullins, Management and Organizational Behaviour,(London : Prentice Hall, 2005),

Muhibin Syah, Psikologi Pendidikan dengan Pendekatan Baru (Bandung: Remaja Rosdakarya, 1997),

Mulyana, Rohmat. Mengartikulasikan Pendidikan Nilai. (Bandung: CV Alfabeta.,2004)

Nana Sudjana, Penilaian Hasil Proses Belajar Mengajar (Bandung: PT. Remaja Rosdakarya, 1995),

.Norman E. Gronlund, Stating Objective for Classroom Instruction (New York: Macmillan Publishing Co. Inc, 1978),

Paul Hersey, Blanchard Keneth. Management of Organization Behavior, (Singapore: Prentice Hall,Inc, 1988),

Perino,Joseph G.,Self-Confidance, (http:/ /www.psychologicalselfhelp.com/intro.htm.on-line), 1999.

Reeve John Marshall, Understanding Motivation and Emotion, (Florida: Harcourt Holt Rinerhart and Wiston Inc, 1992),

Robert M. Gagne, Prinsip-prinsip Belajar untuk Pengajaran. Terjemahan Abdillah Hanafi dan Abdul Manan, Surabaya: Usaha Nasional, 1988 
134 | BELAJEA : Jurnal Pendidikan Islam, Vol. 2, No. 02, 2019

Robert M. Gagne, The Condition of Learning (New York: Hot Rinehart and Winston Inc, 1983),

Rufi'i . Dampak Gaya Kognitif Terhadap Perolehan Belajar Konsep

Statistika.WAHANA Volume 57, ISSN : 0853 - 4403

Saifuddin Azwar, Sikap Manusia, Teori dan Pengukurannya (Yogyakarta: Pustaka Pelajar, 2007), 